\title{
7. Enga Tindi Pii: The Real World and Creative Imagination
}

\author{
Philip Gibbs
}

\section{Introduction}

Found throughout the Enga Province, Enga tindi pii are one of the many traditions of chanted tales in the Highlands of Papua New Guinea as discussed in the other chapters of this book. They are lengthy tales, performed at night by a sole performer (man or woman), primarily for entertainment, but at the same time communicating forms of esoteric knowledge. Nowadays, with social change and new forms of entertainment, tindi pii are uncommon, but they are still performed occasionally, especially in the western parts of the province.

This paper is based on an analysis of seven performances, recorded in different parts of the Enga Province over the past twenty-four years. ${ }^{1}$ The province covers some 12,800 sq km and has over 300,000 Enga speakers. The tales studied come from all the main dialects areas of Enga: Kandepe, Tayato, Yandapo, Mae, Layapo, and Kyaka. ${ }^{2}$ The principal issue for this paper is the manner in which the storyteller uses creative language to draw the listeners into an imaginary world. Reaching that ideal world requires a journey beyond, to where the earth and sky meet in people's imagination.

\section{Literature on tindi pii and related genres}

Some of the early Lutheran and Catholic missionaries circulated private collections of stories. The first Catholic missionary to Enga, Fr. Gerard Bus, has a book in mimeo containing notes on orthography, morphology, syntax, and also twenty stories (n.d.). These are a mixture of short myths and tales - some are almost like what one would call fables or "fairy tales" in English literature.

\footnotetext{
1 Four of the tindi pii studied were obtained through the manager of the National Broadcasting Commission in Wabag. He selected them as some of the best that had been aired over the radio in Enga. The other three were commissioned, the writer going to the area, enquiring who was the best person for chanting tindi pii, and asking him or her to perform a tindi pii for recording.

2 The tindi pii were recorded in the following years: Kandepe (Irai Imijo at Taitenges, 1995); Tayato (Andrew Ipakane Pindap at Mulitaka, 1987); Yandapo (Sikulua Waimben at Sirunki, 1984); Mae-Ambumu (Joannes Kepe at Monogam, 2006); Mae-Tarua (Peter Perambi at Keman, 1993); Layapo (Paul Polyo at Wapenamanda, 2006); and Kyaka (Mrs. Jeny David at Yumbisa, 2007). I wish to thank all those who assisted in collecting, translating, and interpreting, particularly Philip Maso, Joseph Lakane, Joseph Tanda, Maku Lungu, and Joseph Berom.
} 
Anthropologist Mervyn Meggitt collected a number of stories which he categorized as myth and legend - the difference being that between cosmology and sociology, respectively - myth and legend both considered as "history" (Meggitt 1976). Meggitt does not say whether his stories were chanted and the nine examples he provides appear more narrative and less poetic that the tindi pii studied here.

Historian Roderic Lacey distinguished fourteen main types of Enga oral sources, with a typology based on verbal category, formal structure, manner of transmission, purpose, and significance. Under narratives he includes tindi pii and atome pii as fables, tales, myths, and legends (Lacey 1975:83). He notes how these two types of narrative are linked, particularly when myths are interpreted as origin stories or when people borrow from tindi pii to construct a legend about the origin of their clan or phratry.

In recent times Wiessner and Tumu (1998) have drawn upon tindi pii in their project on Enga history. They distinguish between tindi pii as myth, and atome pii as historical tradition. According to Wiessner and Tumu, tindi pii comprise myths and tales, and also origin myths for cults. Atome pii include:

a. Tribal origin traditions (tee pia). These are free-text stories embellished by narrators, but including historical information such as names of tribal founders and their spouses, places of origin, and subsistence strategies of tribal founders.

b. Genealogical sequences linking the narrator to the tribal founder.

c. Historical narratives in free text concerning any historical events of interest.

d. Metaphorical legends in free text recording historical events.

e. Historical traditions of the colonial era in free text.

Other forms of oral tradition include praise poems from the bachelor cults (sangai titi pingi), magic formulas and sacred poetry, songs, and proverbs.

People distinguish between the two narrative forms; for example, tindi pii are normally performed only at night, whereas atome pii can also be told during the day. However, I have found that in practice storytellers do not keep a strict distinction between tindi pii and atome pii, and sometimes use both expressions together. For example, the storyteller says, Tindi wane atome wanaku ongonya paliu siami (As legendary figures the boy and girl lived there ...) or Tindinya atomani lumu ongope (As the story goes ...). This paper focuses on tindi pii and will only consider atome pii embedded in the tindi. 


\section{The plot and the underlying themes}

The main plots in the seven tindi studied in this paper are the following:

Kandepe: A hero, Ipa Lye Puye, is a small orphan. He eventually meets two women. The elder sister is cursed and lives out her life on earth. The younger sister becomes a Sky Being and Ipa Lye Puye matures into a handsome man and joins her there. We (Kandepe Enga) are descendants of the elder sister.

Tayato: Itali Tamba is a little man who eats lizards and sleeps under trees. His brother goes to the place of the cannibals and Itali Tamba goes hunting. He thinks he is shooting a bird, but it is really a woman. She enters into a sexual relationship with him and after he becomes Ipa Pako Pulyo, the two eventually ascend to a legendary place in the sky by means of vines that descend from above.

Yandapo: The last of twenty children was an ugly little boy who ate lizards. He and his brother climb to the top of a mountain where they discover a beautiful flat plain. There they meet two girls. One puts the ugly little boy into her netbag and using magic takes him away. The boy falls into a pool and is transformed into a handsome man. He marries Tapu Enda Ipali. A cannibal eats him but Tapu Enda Ipali recovers his head and brings him back to life.

Mae-Tarua: There are two brothers Lelya and Lelyapa. One is killed by a cannibal. The other brother finds a magic bow and arrows which allow him to kill the cannibal and avenge his brother's death. He has to fall down a cliff to enter an ideal world from which he ascends to the sky, where he could see all corners of the earth.

Mae-Ambumu: Lelyakali Kimala and Tapu Enda Ipali were not born from a natural mother. They lived in a very beautiful place. A cannibal comes and takes Tapu Enda away. Lelyakali searches after her and ends up marrying the cannibal's sister who bears only birds and possums. Eventually Lelyakali Kimala ascends to the sky.

Layapo: A boy was born from a Sky Woman who had married an earthly man. When the boy was pursued by a cannibal, his mother entered into a pig and carried him away on her back. Eventually the boy along with two girls ascends to the sky.

Kyaka: A mythical hero, Sana Walya Asi Kungyapu, had many women friends. One of them is from present-day Mt. Hagen. Sana is killed in a dispute over land. His Hagen friend comes to see him, mixes her own blood with pig's blood for him to eat with greens, and brings him back to life. 
Plots commonly include the following features:

a. A boy who is small and ugly grows to become a strong and desirable man.

b. A boy and girl who have no parents. Often the boy has an advantage. For example, both go to fetch water, but the container given to the girl has a hole in it.

c. A hero figure saves his people from the tyranny of a demon or cannibal.

d. The hero finds or is given a magic bow or a magic package which when used or opened allows him or her to travel immediately to other locations or to have superhuman powers.

e. Often at the end of the tindi, the hero and heroine ascend to the sky (yalya toko 'sky bridge').

Underlying themes include the seeking of adulthood, a quest for beauty, and the search for a better world. Links to the male initiation rites are common. If, in the tale, a man goes to a house in the forest, the house will be beautiful and the garden well planted and flourishing-but there is no other man present. It is looked after by a young girl who is a Sky Woman. In most cases she marries the man and in the end the woman brings the man to the sky. In the Kandepe tale, there are also obvious links to the Kepele ancestral cult.

\section{The characters and their status as spirit beings or as human beings}

Characters in these stories are heroes and heroines, male and female. Very often there is a male or female cannibal or demon. We find contrasting qualities: beautiful and ugly, wild and domestic, younger and older, sociable and unsociable, greedy/selfish and generous. Ipa Lye Puye in the Kandepe tale has never eaten food from a woman or tasted sugar cane from a man and is antisocial and selfish because he eats possums by himself and does not share the meat with others.

Sometimes there is ambiguity about their status as human or some form of spirit being. In the Layapo tale the girls ask, "Is he a real young man or a pututakali (dwarf)?" Others seem human but have special origins. We hear in the MaeTarua tale how the mother of the two boys became pregnant and bore them after eating birds' eggs. In the Mai-Ambumu tale, Lelyakali Kinane and Tapu Enda Ipali have no mother.

The beautiful young woman Tapu Enda Ipali is portrayed as a Sky Being because the only man to have ever "seen" her was the sun. She is described as a woman who does not walk or do the slightest work: Tindinya atomani lumu ongope lea oo, tapu enda ipali nikinya pimalenge lumu ongope (As the myth/story goes, 
she was the sister of the sun). We hear too that Lelyakali Kimala is nikinya kaiminingi (brother of the sun). On other occasions he is called niki lenge (sun eyes or bright eyes - an expression used sometimes in political praise songs today). In the Kyaka tale, Sana Walya Asi Kungyapui's wife has the power to bring him back to life by giving him food containing pig's blood mixed with her own. Some characters appear to be ordinary, but in extraordinary situations. For example two boys struggle to the top of a mountain and find two girls already there-suggesting that the girls are spirit beings.

Some figures are larger than life-like supermen. Even the wild dogs couldn't bite the calf muscles of Pandai Akali Lelya, and when he beat his hand drum the earth shook. He could catch three cassowaries at once in the same trap! Horrifying cannibal figures perform supernatural feats or cause unusual events too. When the hero Kimala shoots the cannibal, there is thunder and lightening from the sky and the whole stone cliff breaks into pieces. The superhuman figures will sometimes undergo a transformation in order to beat the cannibal. For example, in one tale the hero disguises himself as a mosquito, then becomes a young boy. As a "mosquito boy" he doesn't have a name. Later he is recognized as the hero Lelyakali Kimala.

There are moments, particularly at the end of the tales where a human being is transformed into a Sky Being. In the Kandepe story we hear how the handsome young man (who initially was classed among the cannibals) and the young woman arrive at a beautiful flat place covered with nomo grass and there they turn into Sky Beings. In another tale Lelyapa has to fall down a cliff to enter that ideal place, but then ascends to the sky through a sacred plant. In the Tayato tale, Ipa Pako Pulyo is a human hero who ascends to the sky along with a Sky Woman by climbing tatali vines.

The characters are almost always fictional. Among all the tales studied there is only one mention of a living human being whom the listeners would know.

\section{Structure and specialist vocabulary}

Enga tindi pii are usually chanted in a house at night. The lines are of varying length, with internal rhythms somewhat akin to ordinary speech. Sometimes there are lengthened vowels at the end of each line or after a series of lines followed by a pause to allow the teller to take a breath and a chance for listeners to respond with ee, indicating approval (online item 11 is an extract of a performance recorded in the men's house at Mogal, Kandep District, on 11 April 2002). There is repetition either for emphasis, for example, Poo poo mende (a strange wind), with the term poo (wind) repeated, suggesting that it was stronger than normal or poto loo poto kaita, with poto repeated for particular emphasis- 
an expression referring to where the earth and sky meet. At other times an image may be introduced at strategic points in the story for aesthetic purposes, or even to give the teller a chance to decide what comes next.

The most highly appreciated tindi pii use poetic forms quite different from everyday speech. Aside from metaphors and other creative practices (treated in the next section) words used may be particular to a location or any one dialect of Enga. During the study, Enga research assistants had to consult with older persons from the area where the tindi was chanted in order to understand many of the expressions. For example, the Kandepe tindi refers to the hero arriving at Kundaki puu Lemeane. Kundaki is the name of a clan near Ketenge in the Wage region of Kandep and Lemeane a popular name for what would normally be called tae toko or tawe toko (the 'bridge' or place in the sky) in the rest of Enga. A person from Kandepe would understand this, but outsiders might well experience difficulty.

There is also the use of special names in this genre of speech. Sometimes they are a form of "praise name." Thus in the Mae-Tarua tale a bow has a special name, Sangu Muli, because it is a magic bow with "one end pointing to where it gets dark and the other end pointing to where the sun is shining." The person who holds it can fly. The sky too may have different names, such as Embe or Andakuna. Clans have special names, commonly used in traditional songs.

Occasionally the teller will include popular proverbs, as with the inclusion of the saying wanakupi akalina loo mandenge (A woman is born for a man). Most people would recognize the saying, however in this case, the "man" happens to be the cannibal demon.

\section{Creative imagination}

Sometimes the teller will mention rivers, mountains, or places that the hearers are familiar with and then will create an extraordinary scene around those points of reference. For example, one hears of a man being chased up Lupamanda mountain (which the hearers would know), but then there is the fantastic image of him laying his spear across from that mountain to another acting as a bridge for him to cross.

Descriptions are laced with imagery that appeals to the senses: sights, sounds, and even smells. Mountains are described as appearing like eagles' beaks or the sharp beaks of alu birds. The cannibal monster has ugly brown matted hair and one eye on its forehead - as big as a full moon. In the Yandapo tale, people hear 
that as one of the girls goes "her cordyline leaves ${ }^{3}$ were making crackling sounds in the wind." Moreover, the wind is so strong that "both dry and green leaves fall from the trees." In the Mae-Ambumu tale, Lelyakali Kimala smells smoke and as he came closer to the dance ground "he could smell their bodies, they were so crowded." Such images help stimulate the imagination so that listeners are drawn into the tale.

Tapu Enda is described as beautiful - having no marks on her body from hard work or from being beaten. Other attractive woman are said to have "no signs of death on them." In contrast, the daughter of the cannibal is so ugly that her face looks as though "it had been rubbed with pig excrement." The cannibal monster is huge "like the earth and the sky coming." Lelyakali Kimala is so desirable that four girls dance on each side and others behind him, whereas the little lizardeater in the Yandapo tale is said to be ugly with his hair, eyes, and jaw like that of a little opossum. The storyteller goes into detail in describing Itala Tambu: "If you tried to cook him in a ground oven, the fern leaves would be dry. If you tried to eat him, your teeth would break. If you tried to cut him, your knife would become blunt. His head was like a native salt packet and his legs as thin as arrow shafts." It seems he is a tough little fellow.

The imagery is not limited to people. Animals and nature are included also. In the Mae-Ambumu tale all the snakes are seen running away with their eggs in their mouths, and birds are flying northwards with eggs in their beaks - signalling that something terrible is going to happen. There are attractive images too. While the hero is dancing, "the sun couldn't decide whether to set or not ..., and later, morning was hesitating to come. It was like nature saying 'Will I have/let dawn come or not?',

At times one image follows another to develop a scene. In the following example, the storyteller describes an unusual night followed by dawn.

The sky was making strange noises.

The night was filled with something like yumbi cherries.

Then there was a very big rain.

He thought there was something happening and he sat in the house.

Now when it was dawning, there were things of all colours moving around.

When the sky was lit and colourful,

When it was dawning, the sky looked like broken firewood being displayed.

3 These were traditionally worn hanging from a belt like a loincloth. 
It is hard to capture these images in an English translation. The penultimate line above employs words referring to a "spear" and "lighted charcoal" indicating how the sky is not just colourful, but has streaks or shafts of light in the darkness. The underlying meaning is that an extraordinary day was dawning and hunting would be successful.

In another scene we hear how Kupa Lelya and his mother are crying because Lelyapa has not returned from hunting. He was a gardener and had not been hunting before, so they feared for his life and were crying like "rain was falling from a pandanus tree - they were sitting under a waterfall." The listener would know that pandanus trees collect water in their stems, and how when people cut down a wild wapena pandanus tree, especially a young one, a large amount of water pours out. Being underneath it at that time would feel like a waterfall. In this way the storyteller illustrates the extent of them being drenched by their own tears.

At times the meaning is apparent only with sufficient cultural knowledge. In the Tayato tale, the Sky Woman who first appeared to Itali Tamba as a bird says:

If a Yali Kuele man brings a kina shell,

A Mai Makepa man brings a huge pig,

I will release the sane rope at that time.

I have marked it to break the cobwebs.

Below pigs and dogs die, the taro tree dies.

Handsome young men spend time enjoying.

Above I have marked for my Titi clan to live and to care for them.

The woman is referring to herself. She is a virgin and beautiful. Her private parts will be exposed to a man who brings a kina shell or a huge pig. The image of pigs and dogs "dying" refers to bride price as part of the process of marrying a man. In the past, women hid their menstrual blood in moss under a taro tree-known to be a very strong tree. Young men should be careful. If her fluids could kill a taro tree, then most certainly their lives would be in danger. "Above" refers to her breasts, which will nourish her children.

Sexual imagery may be explicit or implicit. Often sexual imagery is linked to scenes of eating. This appears in a brutal way in the Kandepe tale when, after eating a pig's stomach, a man, described as an akali opone mende (newcomer), takes hold of a girl's breast and calls for a knife so he can cut it off and eat it. There are also candid references, such as a comment by the storyteller that "If a man sitting on the men's side would see it (her), he would have an erection," and a woman snapping back, "You come just desiring to see my private parts." Such references add interest to the tale and evoke hilarity among the listeners. 


\section{What sort of world are the hearers being expected to imagine?}

Tindi pii are chanted at night in dark houses, with only the light of embers from the central fireplace. People have eaten, relax, close their eyes, and allow themselves to enter into the imaginary world created in the rhythmic chanting of the storyteller. As noted above, the images appeal to the senses: sight, hearing, smell, touch, but also to people's sense of fantasy. There is geographical depth too. The cannibal asks Lelyakali, "Have you been to the land where rivers reach their destination or the land at the source of these rivers?" The storyteller is putting this question to the listeners as well.

In the Mae-Tarua story, the hero, Kupa Lelya, meets an old man who tests his trust and confidence by telling him to throw himself down a cliff covered with maku trees (which have sharp thorns). At the foot of the cliff, he falls into a swamp and finds himself in a wonderland covered with nomo grass and other beautiful plants. By following the advice of the old man and summoning enough courage, he arrives at a beautiful land. Kupa Lelya decides to go further, so he gives a cooked bird to the wise old man and asks him to show him the road. He is then told to follow the Pima Limbi road (pima limbi being the name of a pandanus tree) and to follow the Lioko road (lioko being another tree where beautiful birds gather). He continues on the journey and at a gate is told to stand on the stem of a lepe plant. From there he reaches his destiny by ascending to the sky. The "gate" and the lepe plant are obvious references to the sangai male initiation rite in which young men would symbolically marry a Sky Woman and gain life and well-being symbolized in the lepe plant (Gibbs 1988). The storyteller uses known items like trees and plants or the initiation rites to anchor a fantastic journey to an imaginary wonderland somewhere here on earth. Only later is there an ascent to the sky, with little elaboration except that niki lenge jia (he becomes "sun-eyes" = the sun).

The imaginary Takapipi Plains are covered in soft nomo grass. We hear in the Yandapo story:

On the top he saw that there was no dirt. It was very tidy.

It was all like tangopipi and the nomo grasses dancing all the way to the end

Laki trees eating and snoring,

Lapu trees eating and snoring,

Konjapipi flowers watching with bright eyes,

Flat field lying still, did you see? 
The listeners are invited to see-with their imagination - the soft grass and the red konjapipi flowers, and to sense the calm: so quiet it as if one might hear the trees sleeping (snoring!).

He saw pearl shells clean without any dirt or blemish

hanging one over top of the other,

parrots with and without bright colours noisily busy near the lioko tree.

The silence is broken by the colourful parrots eating the plentiful lioko fruit. It is a place of peace and harmony, where one does not have to work. The mythical woman Tapu Enda Ipali has no sign of work on her body. For Enga people who value strength and industriousness in women this may seem incongruous, and maybe it is, because this imaginary world contrasts in so many ways with reality.

The path from reality to the imaginary is accomplished by way of a journey. Occasionally the storyteller reminds the listeners that he is talking about an imaginary world. In the Kandepe story, people are informed, "They didn't have to go all the way as far as the mountain-because this is a tindi!"

The storyteller leads the listeners along a familiar path to an imaginary place where something awaits the intrepid traveller:

He went up and up where pigs turned back from digging around.

He reached the place where young men turned back from initiation rites.

He reached the place where people turn back from collecting mushrooms.

He reached the place where the short pandanus trees grows.

He reached the place where the tangu tree grows short.

He reached the place where possums breed.

He reached the place where possums live.

He went on and on.

He reached the place where wild flowers were growing.

He reached the place where short mountain taro trees were growing.

"What am I doing?" he asked.

"When I was a boy I went back from hunting here, now what am I doing?"

"Something is going to happen," he said.

Something does happen - either good or bad. Sometimes the hero encounters a woman, but often the cannibal provides an alternative to the dream world of peace and plenty. Ipa Pako Pulyo, tired of hard labour, decided to journey to the land of the cannibals, thinking that it would be a land of beauty and surplus food. He found that it wasn't like that at all. The cannibal woman's father was 
covered with dirt and drank water from a pool that made him mad. In the MaeAmbumu story, the cannibal journeys to attack Lelyakali and Tapu Enda Ipali. They have eight palisades to protect them and think they are safe. Keoakali the cannibal comes not just breaking through the palisades, but seizing them and throwing them aside! He carries a bow made of mimi timber which others would find impossible to bend. Not only is it mimi, but mimi ii-taka-from which the waste (ii) part on one side has not been removed, making it appear even more primitive!

No matter the difficulties and trials, there is always a happy ending. The Sky Woman saw that Ipa Pako Pulyo was humble and hard working, and when he went to the place of the cannibals to look for a woman, she knew that his life would be endangered, so she came to him in the form of a lae bird. She led him to a place more beautiful than he had ever imagined. It was a place of joy with no labour. Typical for tindi pii, the Kandepe story ends:

The place was occupied with tayakali (sky people)

Hard to describe.

Everything was seen to be perfect.

There was no dirt or dust.

There were handsome and beautiful people with their bodies shining.

\section{Re-imagining traditional items}

Is there a link between such tales and people's lives today? For the most part, tindi pii remain as a traditional genre of chanted tales with little reference to the modern world. There is, however, the occasional reference to modern instruments, as in the Tayato tale when the cannibal's daughter is said to hold up the lower part of a pig's leg as though it were a "pistol." Also sporadically there is a re-imagining of traditional items with links to the contemporary world. For example, opening a magic parcel and flying to another location is now likened to using a plane ticket. Possum fur on the floor of a house is thought to anticipate the modern mattress. Gold mines and associated infrastructural development is seen as a new form of "bridge" or "road" that was anticipated in traditional mythic forms.

To draw conclusions and to think of tindi pii as a form of revelation which has been fulfilled today with modern developments would be to change the genre from tindi into atome-from the ideal to the real. In some ways that would go against the spirit of tindi pii, which use poetic forms appealing to the imagination to lead people into a world that is very different from the world they experience in their daily lives. 
Yet even an imaginary world comes out of a culturally based world view. Material items such as houses or tools, and ideals of beauty or ugliness all draw upon a particular world view. The imaginary ideal world of the tindi pii is not simply one of peace and harmony. For example, many of the tales include incidents that seem very violent to an outsider. In the tindi from Kyaka the woman who goes to see Sana Walya Asi Kungyapu is beaten by all the other women. The youngest brother in the Yandapo tale is continually mistreated and beaten by his brothers. Gender relations in the tales often reflect the tension and violence that occur in everyday life. In the Mae-Ambumu tale, the storyteller makes a point of Tapu Enda being unique because she has no signs of having been beaten. Even in the ideal land of the Takapipi Plains, Lelyakali beats the cannibal's sister (also called Tapu Enda at this stage in the story) because she bears only animals and not real children. In the Kandepe story, a woman protests: "I am not your wife, so stop beating me!" When the man takes hold of the young woman's breast, she is said to urinate and vomit from the pain. The ideal world of the tindi remains a violent world because that is all part of the cultural matter that the storyteller has to work with, be it in a real or ideal world.

\section{Summary and conclusion}

This study of the creative language of tindi pii remains at the level of manifest content of the tales. A structural or functional analysis could be the task for further study. Even considering the characters, the plots, and the creative imagery one can see how tindi pii require great skill on the part of the storyteller, of creativity and facility with poetic forms. It is not only the beauty of language and chant that captures the imagination of the listeners. The skilled storyteller reflects on the human condition of love and fear, fidelity and betrayal. There are scenes of violence between men and women, but there are also moments of tenderness and self-sacrifice, for example when Tapu Enda willingly allows herself to be taken away by the cannibal in order to save Lelyakali from having to fight with the cannibal monster and possibly lose. All Lelyakali could do in response was to weep.

Tindi pii construct an imaginary world based upon and contrasting with life in the real world. That world of Enga, along with people's worldview, is changing rapidly and performances of tindi pii are rare nowadays. It remains to be seen whether Enga people will adapt the tindi pii tradition as a result of these changes or whether it will gradually be relegated to a tradition remembered from the past but no longer part of the contemporary creative imagination. 


\section{References}

Bus, Gerard. n.d. "Orthography, Morphology and Syntax of the Wabag Language." Mimeo.

Gibbs, Philip. 1988. "Lepe: An Exercise in Horticultural Theology." Catalyst 18 (3): 215-34. (also in Doing Theology with People's Symbols and Images, edited by Yeow Choo Lak and John C. England, 159-72. ATESEA Occasional Papers, 8. Singapore: Association of Theological Education in South East Asia, 1989.)

Lacey, Roderic. 1975. "Oral Traditions as History: An Exploration of Oral Sources among the Enga of the New Guinea Highlands." PhD dissertation, University of Wisconsin.

Meggitt, Mervyn J. 1976. "A Duplicity of Demons: Sexual and Familial Roles Expressed in Western Enga Stories." In Man and Woman in the New Guinea Highlands, edited by Paula Brown and Georgeda Buchbinder, 63-85. Washington, DC: American Anthropological Association.

Wiessner, Polly, and Akii Tumu. 1998. Historical Vines: Enga Networks of Exchange, Ritual, and Warfare in Papua New Guinea. Smithsonian Series in Ethnographic Inquiry. Bathurst: Crawford House Publishing. 